\title{
The "Europeanization" of Secessionist Programs: A Study of Montenegro and Catalonia
}

\author{
ALEKSANDAR PAVKOVIĆ \\ Macquarie University, Sydney \\ apavkovi1@gmail.com
}

\begin{abstract}
In 2006, the EU encouraged, facilitated and supervised the secession referendum of Montenegro. In 2014, the EU officials refused to facilitate a similar referendum in its member state Spain, and have so far denied any claims that Catalonia, when independent, would retain its membership of the EU. The paper argues that the EU policy towards secession referenda significantly affected the outcome of secessionist mobilization in these two cases.

In spite of these sharp differences in the EU response, secessionist programs in both countries were 'Europeanised' in a similar way: in Montenegro, secession was aiming to facilitate the EU accession, and in Catalonia, to increase the benefits of retained EU membership. This paper explores the political and demographic context of the Europeanisation of secessionist programs.

The majority of citizens in Catalonia and Montenegro do not identify as Catalan or Montenegrin only. The paper argues that the Europeanization of secessionist programs was, in part, an attempt to widen the appeal of secession to those who are not only Catalan or only Montenegrin.
\end{abstract}

Keywords: Secession, Referendum, National identity, EU, Montenegro, Catalonia

In both Montenegro and Catalonia, a period of peaceful secessionist mobilization resulted in a popular referendum: a legally regulated and EU-supervised referendum in Montenegro in 2006 and the so-called "informal consultation" referendum in Catalonia in 2014. Not surprisingly, the first led to the successful secession of Montenegro and its quick admission to the UN, while the second led to no significant political change and was followed by a slight drop in popular support for the secession of Catalonia. In spite of different outcomes, there are significant similarities as well as differences between these two attempts at secession which this essay will explore. In both Montenegro and Catalonia, secessionist parties insisted that independence/secession from their 'host' state would lead to the membership of the European Union: in both cases, the principal secessionist leaders insisted that once independent, their states would become or remain members of the EU (and also of NATO). It is in this sense that their secessionist programs are said to be 'Europeanized'. ${ }^{1}$

\footnotetext{
${ }^{1}$ Angela K. Bourne, "Europeanization and Secession: The Cases of Catalonia and Scotland”, Journal on Ethnopolitics and Minority Issues in Europe, Vol. 13, No. 3, 2014: pp. 94-120.
} 
Apart from their Europeanization, in both cases the programs contained no threat not even implicitly - to use force to achieve independence. A possible reason for this may be found in the secessionist perceptions of their respective host states, the Kingdom of Spain and the State Union of Serbia and Montenegro (formerly the Federal Republic of Yugoslavia or FRY). In the current national narratives of the Catalans and the Montenegrins, the latter two states have not been labelled as oppressive or repressive: that is, as a state which, at present, is denying either of these two nation(s) its basic civil, political or national rights. In each case, the host state has recognized, to a varied degree, the cultural and political distinctness of the 'non-dominant' nation, and granted the region populated by that nation a high degree of self-government. As the host states were not perceived as oppressive, there was no ground for any call to 'throw off' the oppression by force or to threaten to use force against the state.

One could argue further that the states which recognize the status of their 'non-dominant' nations as distinct nations deserving self-government in effect regard these nations as more or less equal participants in the life of the state. In effect, this should make the 'stateless' nation a 'state nation': that is, a nation which also 'owns' the common state in the same way that the larger or politically more dominant nation does. Yet at some point the political leaders of both 'non-dominant' nations, the Montenegrins and Catalans, came to believe that the host states failed to regard their nations and themselves as equal partners or 'state owners' and campaigned to exit that is, to secede from - the host state. This essay attempts to identify the actions or events which signalled the failure of attempts at inclusion: the events which signalled that the alleged equality of status or partnership had in effect been denied.

The recognition of equal status and of partnership in some form of a 'non-dominant' nation is here crucial: if such a recognition is denied, members of the rejected national group may indeed come to believe that the state they are living in is failing to treat them in the required reciprocal manner. As Lluch points out, political leaders and activists of Catalan nationalist parties expect the Spanish state to follow norms of reciprocity, and it is its perceived failure to do so that led them to espouse a more explicit secessionist stance. ${ }^{2}$ A perceived denial of the expected equal or reciprocal status of a 'non-dominant' nation may be by itself sufficient to trigger the demand to exit the state and establish a state of one's own. The essay will try to show that this is what happened in both Montenegro and Catalonia.

In both cases, specific acts of the central government were interpreted by citizens and/or political leaders as denials of equal status and equal voice in the political life of the state, and as such triggered a change of political orientation of major parties towards secessionism both in Montenegro and Catalonia. However, the process of change towards secessionism was significantly different. In Catalonia, but not in Montenegro, this change was a result of mass mobilization for a secession referendum which was initially not organized by political parties but by civil society groups.

\footnotetext{
${ }^{2}$ Jaime Lluch, "Internal variation in sub-state national movements and the moral polity of the nationalist," European Political Science Review, Vol. 4, 2012, pp. 433-460, doi:10.1017/S1755773911000269. Lluch interprets the political leaders' and activists' expectation of reciprocity as a belief that a state should form a 'moral polity' which has moral obligations to nations or national groups living in it. This is a normative worldview shared by at least some normative theorists of secession who aim to identify and justify moral rights to secession. As do not see any theoretical reasons to assign moral rights to national groups (see Aleksandar Pavković, "The Right to Secede: Is it Really Needed?” The Asghate Research Companion to Secession, ed. Aleksandar Pavković and Peter Radan, Farnham: Ashgate, 2011, pp. 239-53) and I see no need to discuss this kind of worldview in the present paper.
} 
Another significant difference which this paper will examine is the involvement of the EU institutions and officials in the secessionist project. In Montenegro, the EU was actively involved in setting up the legal and political framework for its secession referendum and in regulating the process and outcome of the referendum. In contrast, in Catalonia, EU officials openly rejected one of the major planks of the Catalan secessionist platform - that an independent Catalan state would remain in the EU and EU bodies refrained from any comment or suggestion regarding the possible referendum. While the EU initiated and regulated the process through which Montenegrins could express their preference for independence or secession, it refused to do so in the Catalan case, and actively undermined the Catalan secessionist program.

\section{Montenegro: a de facto secession followed a secession referendum under EU supervision}

Milo Djukanović, the prime minister who in 2006 led the secessionist coalition (the Bloc for Independence), was also the prime minister who in 1992 had led the pro-union coalition. In 1992, he won the first referendum with 95 per cent votes cast for the union with Serbia (in the Federal Republic of Yugoslavia or FRY). At the time, he took the traditional pan-Serbian view of Montenegrin identity, asserting that Montenegrins are by origin Serbs and belong to the Serb people. 3 By 1996, he came gradually to regard Montenegrins as a nation distinct from the Serbs, with whom they shared little but a state in common. In 2000, he and his ruling party denounced this common state as illegitimate, and finally seceded from it in 2006.4

The beginning of Djukanović's transformation was a split in his own party, the Democratic Socialists (ex-Communists) of Montenegro. In 1996, Djukanović denounced the elections in Serbia, which the then Serbian president Miloševic won, as fraudulent, thus supporting the Serbian opposition. 5 Another faction in his party, led by the then president of Montenegro Miomir Bulatović, continued to support Milošević. ${ }^{6}$ That faction eventually split from the Democratic Socialists to form a new party. However, in 1998, this party lost the parliamentary elections in Montenegro. At this point, Milošević appointed the leader of the defeated party, Bulatović, as the prime minister of the common state, federal Yugoslavia. The Montenegrin government, led by Djukanović, denounced this appointment "as another attack on the constitutional order and equitable position of Montenegro in Yugoslavia" (emphasis added), (Morrison 2006, p.165).7 The federal government, led by a Serbian president, thus denied the equal status of Montenegro by appointing the principal opposition leader instead of an appointee of the majority coalition government in Montenegro.

Djukanović's government responded by disassociating Montenegro from Serbia through the policy of "creeping independence". In 1998, it took over control of the customs and foreign trade; and in 1999, it introduced the German mark as a legal

\footnotetext{
3 In a speech, Djukanović is reported as saying, "Montenegrins are proud of their Serb origin and the statehood of Montenegro, of the history of the Serb people". TV Politika, "Verovali ili ne, Milo Đukanović: Crnogorci su ponosni na svoje srpsko porijeklo!”, TV Politika, 29 August 1990, accessed 15 May 2015,

http://eizbori.com/verovali-ili-ne-milo-dukanovic-crnogorci-su-ponosni-na-svoje-srpsko-porijeklo/

4 From 1991 until the present, the current prime minister of Montenegro, Milo Djukanovic, has dominated

Montenegro's political life. He was first elected prime minister in 1991, as a member of the League of Communists of Montenegro, and has since held the office of prime minister or president of Montenegro until the present (2016) with an interruption of around 3 years. Hence, the continuous reference to him and his party in this paper. 5 Kenneth Morrison, Montenegro: A Modern History, London: I.B. Tauris, 2006, p. 154.

6 ibid., p. 156.

7 ibid., p. 165, emphasis added.
} 
tender in Montenegro. It enlarged and militarized its police forces and created an independent foreign service, establishing missions and embassies abroad. By 2000, the Yugoslav Army and air traffic control were the only institutions in Montenegro remaining under the control of the federal Yugoslav government, still led by the Montenegrin Bulatović. ${ }^{8}$

This policy was publicly and financially supported by the US and the EU as a strategy for undermining Milošević's regime in Yugoslavia/Serbia. As a result, this small de facto state of 650,000 inhabitants became, after Israel, the second largest per capita recipient of direct US financial assistance. 9 While supporting "creeping independence", the EU and the US initially opposed Djukanović's government's plans to declare de jure independence. When the Miloševic regime in Serbia fell in 2000, the EU initiated and chaired the negotiations between the new Serbian government and Djukanović's government. The result was an agreement in 2003 to establish a new confederal union, the State Union of Serbia and Montenegro. The agreement provided for a referendum on independence to be held, at the earliest, in 2006. ${ }^{10}$ The referendum was duly held in May 2006 and Djukanović's coalition for independence won, although it was only 2,300 votes over the required threshold of 55 per cent of the votes cast. ${ }^{11}$ The opposition called for a recount, alleging organized fraud, but the Referendum Commission, headed by the EU special representative, rejected these allegations out of hand, proclaiming the results valid. ${ }^{12}$

The above highly selective account of Montenegro's secession highlights the distinctive aspects of the process leading to a successful (albeit contested) referendum on independence and Montenegro's exit from the State Union. First, the triggers that started the process were unrelated to the questions of national identity: these were the disputes in 1996 and 1998 over Montenegrin political support for the majority partner in the joint state (that is, the ruling Serbian parties). These were not disputes over the recognition of Montenegrin national identity or national narrative. Second, the host state, Yugoslavia, proved to be too weak and unwilling to resist an almost complete takeover of the federal institutions by the Montenegrin government, which resulted in its de facto independence. Third, from 1998 onwards, the US and EU provided financial and logistic support, enabling the government of Montenegro to achieve de facto independence and to hold the referendum leading to de jure independence. As we shall see, the second and third aspects are missing from the Catalan case.

The major obstacle that Djukanović's government faced was the lack of popular support for de jure independence, which was due, at least in part, to the absence of an overall majority of Montenegrins: that is, individuals who identify themselves as Montenegrin only. The problem was not apparent in the referendum of 1992: in the Montenegro census of 1991, 61 per cent of inhabitants were Montenegrins and only 9.34 per cent were Serbs. In the census of 2003, the number of Montenegrins drastically declined: there were only 43 per cent Montenegrins, as against 32 per cent

\footnotetext{
8 ibid., p. 182.

9 ibid., p. 166; Alternative Information Network (AIM), "Montenegro and Western Donors: More assistance after all", 2 September 2001, accessed 30 September 2015,

http://www.aimpress.ch/dyn/trae/archive/data/200105/10505-002-trae-pod.htm

${ }^{10}$ Morrison, 2006, p. 189.

${ }^{11}$ Zoran Oklopčić, "Constitutional Politics of Secession: Travelling from Quebec to Montenegro and back)?" in The Ashgate Research Companion to Secession, ed. Aleksandar Pavkovic and Peter Radan, Farnham, UK: Ashgate, 2011, p. 141.

${ }^{12}$ BBC, "Montenegro vote result confirmed", 23 May 2006, accessed 28 August 2013,

http://news.bbc.co.uk/2/hi/europe/5007364.stm
} 
Serbs (although in the 2011 census, the percentage of Montenegrins increased to 44 and the percentage of Serbs decreased to 28). ${ }^{13}$ Explanations for this change in selfidentification are highly contested, but one can note that since 1996, the Montenegrin government has supported a redefinition of the Montenegrin identity as distinct and exclusive of the Serb identity via the following measures: the official language was restandardized as the Montenegrin language, distinct (with the addition of two new letters of the alphabet) from the Serbian language; a separate Montenegrin Orthodox Church was recognized; and the union in Serbia was presented in official histories and textbooks as an imposition of foreign Serbian rule, resisted by true Montenegrin patriots. A new Montenegrin national anthem, introduced in 2004, proclaims, in the verses written by a Montenegrin separatist (who had collaborated with fascist occupiers during World War II), that Montenegro, as a separate state, is eternal. As a result of these redefinitions of national identity, a Montenegrin no longer could easily claim that he or she is also a Serb: the latter category was decidedly classified as unMontenegrin (if not anti-Montenegrin). ${ }^{14}$ Faced with the either/or choice between the two, a large number of Montenegrins, in particular those living in the northern part of Montenegro close to the border with Serbia, chose to declare themselves Serbs. Their decision reduced the percentage of Montenegrins in Montenegro to less than half of the population.

The referendum campaign in 2006 reflected this fact. The pro-independence campaign avoided any mention of the exclusive Montenegrin national identity (which demands a state of its own) and instead focused on the promise of a prosperous "Euro-Atlantic" future for an independent Montenegro. 15 The major obstacle to such a future, the proindependence campaign insisted, was Montenegro's union with Serbia, burdened as Serbia was with its recent wars with NATO and EU member states and the unresolved question of Kosovo. Therefore, a prosperous "Euro-Atlantic" future could be assured only without Serbia. Yet the slim and contested margin of victory for the independence parties suggests that the referendum promise of Montenegro's quick solo entry into the EU/NATO did not appear to attract a majority of the Serb voters in Montenegro. ${ }^{16}$

\section{Catalonia: from mass mobilization to an informal consultation of the people}

The concept of Catalan national identity, as it was developed during the nineteenth century, emphasized Catalan distinctness. The leading intellectual figure of Catalanism in this period, Valenti Almirall, argued that Catalans are both in their origins and cultural traditions closer to the 'Latin race', and thus to the European mainstream, than the Castilians (who were the ruling group in Spain). ${ }^{17}$ The Catalans, it was maintained,

\footnotetext{
${ }_{13}$ Jelena Dzankic, "Cutting the mists of the Black Mountain: Cleavages in Montenegro's divide over statehood and identity", 2011, academia.edu, p. 2. Accessed on 12 February 2016 at

https://www.academia.edu/5310438/Cutting_the_mists_of_the_Black_Mountain_cleavages_in_Montenegro_ s_divide_over_statehood_and_identity

${ }_{14}$ The Montenegro census of 2011 introduced for the first time the category of Montenegrins-Serbs as well as Montenegrins-Muslims and Montenegrins-Bosnians. There were only 0.30 per cent of Montengrin-Serbs in Montenegro (Monstat, Statistical Yearbook 2011, Podgorica: Montenegro Statistical Office, 2011, p. 46). 15 Mondo, "Prvi predreferendumski skup za nezavisnu CG", Mondo, 29 April 2006, accessed 20 July 2015, http://mondo.rs/a2118o/Info/Srbija/Prvi-predreferendumski-skup-za-nezavisnu-CG.html

${ }^{16}$ This section and the one that follows draws upon parts of Aleksandar Pavković, "How to Secede in Europe: Beyond Nationalism,' Nationalism in Asia and Europe, ed. Wolfgang. Hofmeister, Paul. Rueppel, Megha Sarmah, Singapore: Konrad Adenauer Stiftung, 2015, pp.41-53.

${ }_{17}$ Angel Smith, The Origins of Catalan Nationalism, 1770-1898, Houndmills, UK, Palgrave-Macmillan, 2014, p. 155 .
} 
have a distinct language and a distinct society with its customary way of life and folk festivals, a history of an independent state and a growing high culture (literature, arts, music). In short, being Catalan was distinct from being Castilian or Galician, and from being a member of any other group in Spain. This, as we shall see, did not preclude many individuals from feeling that they are both Catalan and Spanish, but this kind of dual identity meant sharing distinct cultural traits and being able to use two distinct languages, Catalan and Castilian (which formed the standard Spanish). Already in the nineteenth century, national narratives linked to the Catalan identity ranged from those promoting federal or confederal union with the Spanish state to those promoting an independent state. Fernando Solis neatly classifies the current narratives into two broad categories: differential (two different nations, one state) and disjunctive (two different nations, two states). According to Solis, the largest Catalan party, the centreright Convergence and Unity, which alone ruled Catalonia until 2003, has endorsed the former; while the two smaller left parties, the Republican Left of Catalonia and the Party for Independence, endorsed the latter. ${ }^{18}$

Once Convergence and Unity lost power in 2003 to a coalition of left and socialist parties, the new government (Generalitat) of the Autonomous Region of Catalonia put forward a new Statute of Autonomy which recognized Catalans as a distinct nation, made Catalan the preferred language in Catalonia, enabled the Catalan government to set and collect some taxes and reduced the overall fiscal contribution of Catalonia to Spain. Although this Statute passed the referendum in Catalonia and the Spanish parliament, the Spanish Constitutional Court, on 28 June 2010, struck down as unconstitutional or legally void several articles of the Statute which dealt with the Catalan language preference and Catalonia's fiscal contributions. The Court also pointed out that Spain is the only nation recognized by the Constitution of Spain, but did not rescind the Statute's claim in its preamble that the Catalans are a nation. ${ }^{19}$ The Court's decision triggered mass protests in Catalonia, bringing an estimated million people onto the streets of Barcelona on 9 July 2010 in a protest which was organized by an ostensibly cultural organization, Ómnium Cultural, under the slogan "We are a nation. We decide". ${ }^{20}$ The next stage of popular mobilization was a series of unofficial local referenda, organized by a variety of civil society organizations, in support of independence. One of the largest Catalan civil society organizations, Assamblea Nacional Catalana (ANC), organized the demonstration on 11 September 2012, "designed to constitute an unequivocal call for Catalonia's politicians to start a process of secession". ${ }^{21}$ In this, the ANC and other organizations succeeded: the largest party, Convergence and Unity, and its leader opted for a referendum on independence, and, later, for independence. ${ }^{22}$

The Spanish Court's rejection of the Catalan Statute (or, rather, of its several important clauses) was clearly perceived by a large segment of the Catalan electorate as a denial of recognition of equal status of the Catalans. This denial led first to the mobilization

\footnotetext{
${ }^{18}$ Fernando León Solís, Negotiating Spain and Catalonia: Competing Narratives of National Identity, Bristol: Intellect, 2003, p. 4.

${ }_{19}$ Montserrat Guibernau, "Secessionism in Catalonia: After Democracy", Ethnopolitics, Vol. 12, No. 4, 2013: p. 383; Kathryn Crameri, Goodbye Spain? The Question of Independence for Catalonia, Brighton: Sussex Academic Press, 2014, p. 44.

${ }^{20}$ Crameri, 2014, p. 44.

21 ibid., p. 48.

22 ibid., p. 50.
} 
for a secession referendum and then to the transformation of the largest political party in Catalonia, previously pro-union, into a secessionist party.

Partly as a result of this transformation of the largest party into a secessionist party, the 2012 elections returned a majority in the Catalan parliament favouring independence. ${ }^{23}$ The elections were followed by an even larger demonstration than any previous one, this time in support of independence. In 2013, the Catalan parliament set the referendum on independence for November 2014. However, the Spanish government banned the referendum and the Spanish Constitutional Court proclaimed it unconstitutional. The unofficial referendum, called a "consultation of the people," was held on 9 November 2014, and was organized by the Catalan political parties and civil society organizations. With a turnout of 36 per cent of registered voters (2.2 million), 80 per cent voted for independence. Since many voters opposed to independence abstained from voting, a larger turnout in an official referendum would probably have failed to produce a majority for independence. ${ }^{24}$

A poll conducted in April 2015 indicated that only 39.1 per cent of the people polled in Catalonia supported an independent state of Catalonia. 25 This is a significant decrease from the 57 per cent support for independence that was registered in the polls in 2012/13. In 2012, the support for independence extended well beyond the group who identified themselves exclusively as Catalan: in 2012, this group comprised only 31 per cent of the population of Catalonia. Most of the population holds some form of dual identity: in 2012, 26 per cent identified themselves as "more Catalan than Spanish", 36 per cent as "as Spanish as Catalan" and 2.6 per cent as "more Spanish than Catalan". ${ }^{26}$ 87 per cent of those who identified themselves as exclusively Catalan and over 60 per cent of those who identified themselves as more Catalan than Spanish or as as Spanish as Catalan said they would vote for independence. ${ }^{27}$ These figures suggest that most support for independence would come from people who identified themselves as Catalan either exclusively or as part of a dual identity (Catalan/Spanish). Other researchers also point out that the "those with the strongest preference for independence are the most likely to justify this with reference to their Catalan identity". ${ }^{28}$ But since only a minority of the population identify themselves exclusively as Catalan - a smaller percentage than those who identify themselves equally as Spanish and Catalan - the pro-independence campaign in Catalonia could not and did not focus on the distinct Catalan national identity, nor even on the narrative of the recovery of independent Catalan statehood. The pro-independence campaign instead focused on two related economic issues: first, on the economic advantages of abolishing the transfer of tax receipts to the Spanish state and gaining fiscal independence for Catalonia, ${ }^{29}$ and second, on the economic (and political) advantages of membership of the EU as an independent state and not as a region of another state. 30

\footnotetext{
23 Guibernau, 2013, p. 388.

${ }^{24}$ Angel Smith, "Where next for Catalonia after its unofficial referendum?”, 12 November 2014, accessed 30 September 2015, http://theconversation.com/where-next-for-catalonia-after-its-unofficial-referendum-34028 25 Baròmetre d'Opinió Política (BOP),1a onada 2015 - REO 774Centro d'Estidis d'Opinio, Barcelona, 2015, accessed 30 August 2015, ceo.gencat.cat/ceop/AppJava/pages/home/fitxaEstudi.html?colId=5268\&lastTitle=Bar\%F2metre+d\%27Opini\%F 3+Pol\%EDtica+\%28BOP\%29.+1a+onada+2015

${ }^{26}$ Montserrat Guibernau, 'Prospects for an Independent Catalonia' International Journal of Politics, Culture and Society, Vol. 27, 2014: p. 20.

${ }^{27}$ Ivan Serrano, “Just a Matter of Identity? Support for Independence in Catalonia”, Regional \& Federal Studies, Vol. 23, 2013: 5, 527.

${ }^{28}$ Crameri, 2015, p. 60.

29 Serrano, 2013, p. 534.

30 Bourne, 2014.
} 
In its pro-EU integration aspect, the Catalan campaign resembled the "Euro-Atlantic" integration aspect of the campaign for Montenegrin independence. But in contrast to the case of Montenegro, EU officials explicitly denied the possibility of Catalonia gaining immediate membership of the EU and the Eurozone upon independence. ${ }^{31}$ Nonetheless, the leaders of the pro-independence parties continued to reiterate the need for Catalonia to remain in the Eurozone. ${ }^{2}$

The importance of Catalonia's continuing membership in the EU for the Catalan voters is borne out in several opinion polls conducted by Metroscope regarding voting intentions in a hypothetical referendum on secession of Catalonia. Its November 2012 poll indicated that if independence of Catalonia required its leaving the European Union, only 37 per cent of the respondents would vote for independence, while 50 per cent would vote to stay in Spain. 33 In November 2015, if it were clear that the independence of Catalonia would lead to its immediate exit from the European Union, 36 per cent of the respondents would vote for independence and 55 per cent to remain in Spain.34 From these polls, one could infer that the secessionist leaders have no option but to insist that an independent Catalonia would remain a part of the EU. If they were to suggest that an independent Catalonia could thrive even without continuing its membership of the EU, their secessionist program would most likely lose the support of the majority of the Catalan voters.

At the elections for the regional parliament in September 2015, all the secessionist parties gathered 47.8 of votes cast (in the 77.44 per cent turnout of registered voters), which secured them a working majority in the regional parliament. The leader of the main secessionist party, Convergence and Unity, Artur Mas, had already unveiled a program of achieving independence within eighteen months. The proposed program involved both negotiation with the central Spanish government and the establishment of Catalan state institutions including armed forces. 35 The Spanish government, under the centre-right Popular Party, reiterated its rejection of Catalan independence as illegal and vowed to use the Spanish judicial system to block any move towards independence. But following the general elections in December 2015, the Popular Party was not able to form a government in Spain, and, at the time of writing (March 2016), three months after the elections, the parliamentary parties have still been unable to agree on a coalition government. The latest Spanish election in June 2016 failed to produce a majority for any one party; hence once again the Popular Party will have to try to form a coalition with a working majority in the parliament. Meanwhile, the president of Catalonia, Carles Puigdemont, who was elected in January 2016 to replace Artur Mas, stated in March 2016 that Catalonia could achieve independence without

\footnotetext{
31 ibid., pp. 106-107.

$3^{2}$ Lucía Abellán, "Mas asegura que la importancia de Cataluña evitará la salida del euro,” El País, 20 September 2013, accessed 2 September 2015,

http://politica.elpais.com/politica/2013/o9/19/actualidad/1379620052_367812.html

33 José Juan Tohar, "Hipotético referéndum sobre la independencia de Cataluña," Metroscopia, 21 November 2015, accessed 10 March 2016, http://metroscopia.org/hipotetico-referendum-sobre-la-independencia-decataluna/

34 Metroscopia. “Qué votarían hoy los catalanes en un referéndum sobre la independencia?” 21 November 2015, accessed 10 March 2016, http://metroscopia.org/pulso-sobre-independencia/

35 Tobias Buck, “Catalan president steps up breakaway plan," Financial Times, September 2015, accessed 3

October 2015, http://www.ft.com/cms/s/o/efb9cd2c-55fc-11e5-a28b-5022683od644.html\#axzz3nOsrp34q
} 
having to reach an agreement with the Spanish government. ${ }^{36} \mathrm{How}$ that is to be achieved, if at all, is yet to be seen.

The "Europeanization" aspect of the pro-independence campaign in Catalonia, unlike the similar "Euro-Atlantic" aspect of the pro-independence campaign in Montenegro, appears to have attracted significant numbers of non-Catalan voters to the independence cause. In contrast, the first economic advantage listed above - the demand for fiscal autonomy/independence from Spain - correlates with individual support for independence, regardless of the individual's national identity according to Serrano.37 Serrano also identifies several other factors not directly linked to national identification that also impact on support for independence. 38

\section{How to attract those who are not 'true believers' to a secessionist project}

Prior to embarking on the political mobilization which led to the independence referendum, political parties in Montenegro and Catalonia faced a similar set of issues. First, the group most likely to support secession - those who identify themselves as Montenegrins or Catalans - were in the minority in each region (42 and 31 per cent respectively). Second, there was no evidence at that time that a significant portion of voters supported secession (in 2009, only around 20 per cent of Catalans supported independence). The largest or ruling parties in Montenegro and in Catalonia had until then been staunchly pro-union: that is, anti-secessionist parties. As a result of secessionist mobilization, the ruling parties were transformed into secessionist parties and the majority of voters in both countries expressed support for independence at some point in the process of mobilization. This was achieved in spite of the fact that the self-identified Montenegrins and Catalans remained in the minority, just as they were prior to the secessionist mobilization.

How did the secessionist parties - and the coalitions they formed - attract support beyond the core of true believers: that is, those who identify themselves with the dominant national group? This essay does not, unfortunately, offer an answer to this question. But it does identify a significant aspect of the pro-independence campaigns in both Montenegro and Catalonia which made no reference to the national identity of the dominant national groups - the "Europeanization" of the secessionist platform or "the EU promise". The leaders of the secessionist campaigns in both regions insisted that the independence of their new state would bring to their citizens a more advantageous integration into the European Union than could be achieved or had been achieved in the current joint state. The advantages accruing from EU membership are, by definition, not limited to the members of specific national groups within the state but to all of its citizens, regardless of their national identification. The appeal to the advantages of EU membership thus goes beyond any national narratives based on the

\footnotetext{
${ }^{36}$ Tobias Buck, “Catalonia can secede without Madrid's backing, says new leader," Financial Time,s 16 March 2016, accessed 18 March 2016, http://www.ft.com/cms/s/o/f37ef1a4-ec4b-11e5-bb792303682345c8.html\#axzz43LfFVtkP

37 Serrano, 2014, p. 540.

${ }^{38}$ Ibid., pp. 540-541. As Dowling notes, the secessionist mobilization was assisted by “...by the rise of neopopulisms and new political discourses. Independence became the catch-all solution in the period after 2003. The narrative appealed to ever expanding sectors of the population, being the only Catalan political discourse that had not been discredited and being sufficiently amorphous to have projected onto it a range of aspirations". Andrew Dowling, "Accounting for the Turn towards Secession in Catalonia”, International Journal of Iberian Studies, Vol. 27, Nos. 2-3, 2014: pp. 224-225.
} 
national identity which characterizes modern nationalism in Europe, including the Catalan and Montenegrin nationalism.39

As we noted, the triggers for secessionist mobilization were in both cases the actions of the central government, which were interpreted as a denial of recognition of equal status or partnership: in the case of Montenegro, the appointment of a Montenegrin opposition leader in 1996 as the prime minister of the shared state, Yugoslavia; and in the case of Catalonia, the Spanish Constitutional Court's decision in 2010 to invalidate several articles of the Catalan Statute which placed Catalonia on an equal footing with the Spanish state. Yet the constitutions of the joint state (the FRY in 1998 and the Kingdom of Spain in 2010) did not envisage or allow for a procedure of secession or detachment of any part of the joint state.

Notably, the capacity of the two states, Yugoslavia and Spain, to counter secessionist mobilization and the resulting takeover of state institutions greatly differed. In 1998 the Federative Republic of Yugoslavia was a new state, formed only in 1992, and was significantly weakened by the wars fought in Croatia and Bosnia and Herzegovina and the resulting international sanctions. It was also a highly polarized state, with an opposition which denied the legitimacy of the regime under Milošević and a large Albanian minority controlling a parallel state-structure in Kosovo. Under these circumstances, the Yugoslav government showed neither willingness nor capacity to prevent the takeover of almost all state institutions by the Montenegrin government, including a separate currency and a foreign service. The Spanish state, in spite of the continuing recession and the continuing severe political instability, has so far been able to maintain its state institutions and to enforce its laws in Catalonia and to prevent a state-approved referendum on independence. In short, in spite of a large surge of popular support for independence and the resulting pro-independence legislation in the Catalan parliament, one cannot yet identify any features of the "creeping independence" in Catalonia observed in the case in Montenegro. At the time of writing (June 2016), the Catalan government, while committed to the creation of institutions independent from the Spanish state, has not created any such institutions as yet, nor has it taken over any of the institutions controlled by the Spanish state.

But perhaps most importantly, in spite of the systematic efforts of the Catalan government to find support for its independence in Europe and the US, neither the US nor the EU nor its member states have offered any support. $4^{\circ}$ On the contrary, top EU officials publicly denied the Catalan leaders' claims that Catalonia would, upon independence, gain EU membership, thus undercutting an important plank of the secessionist platform..$^{41}$ Thus, in the case of Catalonia, the EU took, as Bourke argues, not a neutral but an obviously anti-secessionist stance. Whether the EU will abandon its anti-secessionist stance, as a result of the Catalan government's commitment to achieving independence with or without the agreement with Spain as reiterated in March 2016, is still an open question.

This is in sharp contrast to the EU's policy towards Montenegro. The EU from the start supported the secessionist leaders and their policy of "creeping independence" by providing financial and logistic support. Furthermore, the EU was involved in the negotiation of a new union treaty and a constitution which provided for an

\footnotetext{
40 Bourne, 2014, pp. 101-104.
}

41 ibid., p. 106. 
independence referendum in Montenegro. The EU appointed a special representative, who became the chair of the Referendum Commission. The EU in effect set the threshold of 55 per cent of those voting as the success criteria for the referendum and, following the referendum, rejected all the opposition's complaints regarding the irregularity of the voting. In effect, the EU, through its representative, set the terms of the referendum and legitimated its results, resulting in the independence of Montenegro. ${ }^{42}$

The EU had, of course, neither legal grounds nor effective means (nor, of course, any interest) to do anything similar in Spain in the case of Catalonia. But had the EU supported the secessionist leaders in the same way as it did in Montenegro and had it ensured that the referendum was held in Catalonia at the peak of popular support for independence (and promised to recognize its independence), Catalonia would have probably become an independent state, just as Montenegro did. But, contrary to the secessionists' promise, Montenegro, almost ten years since its independence, has not yet gained entry into the EU - and will not gain it any time soon. Although not independent, Catalonia is still part of the EU as an autonomous region of Spain.43

$4^{2}$ Oklopčić, 2011, pp. 140-141.

43 I would like to thank the anonymous referees of the article for their insightful comments and my son Andrej for editing the article. 